\title{
Aligning Best Practices in Student Success and Career Preparedness: An Exploratory Study to Establish Pathways to STEM Careers for Undergraduate Minority Students
}

\author{
Kimberly D. Kendricks ${ }^{\mathrm{a}}$, Anthony A. Arment ${ }^{\mathrm{b}}, \mathrm{K}$. V. Nedunuri ${ }^{\mathrm{b}}$, Cadance A. Lowell ${ }^{\mathrm{b}}$ \\ ${ }^{\mathrm{a}}$ University of Nevada, Las Vegas, ${ }^{\mathrm{b}}$ Central State University
}

\begin{abstract}
Undergraduate minority retention and graduation rates in STEM disciplines is a nationally recognized challenge for workforce growth and diversification. The Benjamin Banneker Scholars Program (BBSP) was a five-year undergraduate study developed to increase minority student retention and graduation rates at an HBCU. The program structure utilized a family model as a vehicle to orient students to the demands of college. Program activities integrated best K-12 practices and workforce skillsets to increase academic preparedness and career readiness. Findings revealed that a familial atmosphere improved academic performance, increased undergraduate research, and generated positive perceptions of faculty mentoring. Retention rates among BBSP participants averaged 88\% compared to 39\% among non-participant STEM peers. The BBSP graduation rate averaged $93 \%$ compared to $20 \%$ for non-participants. BBSP participants were more likely to gain employment in a STEM field or enter into a professional study. This paper furthers the body of research on STEM workforce diversity and presents a transferrable model for other institutions.
\end{abstract}

Keywords: Underrepresented minorities, family model, retention, faculty mentoring, undergraduate research

Despite the financial gains from investing in higher education, employer demand for skilled workers continues to outpace supply, particularly in the science, technology, engineering, and mathematics (STEM) fields (Carnevale \& Rose, 2011). The need to better prepare undergraduates for evolving high-tech STEM careers has been clearly documented (NSF, 2018; NSB, 2015; Carnevale \& Smith, 2013). Research shows that by 2020, the workforce will be severely underemployed in STEM (U.S. Bureau of Labor Statistics, 2017), and by 2060, minorities are expected to be the majority of the U.S. population (U.S. Census Bureau Report, 2014). It is then pivotal to increase diversity in the workforce to reflect the country's changing demographics. The United States faces two ongoing challenges in preparing the next generation of STEM majors: the improvement of undergraduate retention and graduation rates and the increased entrance and graduation of minorities from STEM graduate programs.

\footnotetext{
cc (i) $\odot$ Creative Commons CC-BY-NC-ND: This article is distributed under the terms of the Creative Commons Attribution 4.0 License (http://creativecommons.org/licenses/by/4.0/) which allows others to download your works and share them with others as long as they credit you, but they can't change them in any way or use them commercially.
} 
In 2009, President Obama launched Educate to Innovate, a national program catalyzing federal funding agencies and educational organizations to work together differently to create a STEM-capable U.S. workforce (White House Press, 2009). Together, and with additional federal investments (i.e., One Decade, One Million More Graduates and STEM for ALL), President Obama solidified a cross-agency priority that accelerated a national push to improve academic preparedness and career readiness in STEM. The goal: to strengthen pathways to graduate/professional study and/or an industrial career in STEM (PCAST, 2012; Obama, 2016).

To assist colleges and institutions with reforming their approach to retaining and graduating STEM students, the President's Council of Advisors on Science and Technology (PCAST) directed universities to coordinate their degree programs with curriculums of K-12 schools, adopt validated teaching practices, and build industrial partnerships to diversify STEM pathways (PCAST, 2012; Carnevale \& Hanson, 2015).

Previously, the onus fell on K-12 systems to address the lack of student readiness for college. K-12 systems aligned high school graduation standards with college entrance requirements, reexamined secondary assessments such as high school exit exams and proficiency tests, and/or hired college counselors (American College Testing, 2016; Porter, Polikoff, \& Smithson, 2009; Larson \& Novak, 2002). A 2013 study supported by the Lumina Foundation proposed a framework for how universities could better participate in the process of improving student readiness; according to this framework universities should: engage in dialogue with K-12 systems, create bridging infrastructure to tune learning outcomes with degree/career expectations, and commit to accountability measures (Conley \& Gaston, 2013; Adelman, Ewell, Gaston, \& Schneider, 2014; Jankowski \& Marshall, 2015).

In the state of Ohio, colleges and universities were guided by the Department of Education to develop statewide governing committees to facilitate dialogue, strategy, and implementation with K-12 systems (Ohio Board of Regents, 2011; Ohio Board of Regents, 2014; Ohio Department of Education, 2014). Colleges and universities instituted dualcredit options, expanded student learning of the STEM knowledge-base, formed new courses that better prepared students for careers within their discipline of study, created opportunities to reduce remediation, and established academic support programs that better served all types of students, especially students from underserved populations, i.e., firstgeneration students and ethnic minorities (Complete College Ohio Task Force Subcommittee Report, 2014; Complete College Ohio Task Force Report, 2011; Ohio Board of Regents, 2014). This paper discusses how one institution in Ohio developed an academic support program for undergraduate minorities that increased STEM retention, graduation, and placement into the STEM workforce.

The Benjamin Banneker Scholars Program (BBSP) was established in 2008 to study a new approach to increasing minority student retention and graduation in STEM. The program integrated best practices in academic achievement and career readiness to (1) orient students to the academic demands of college and (2) equip students with the necessary skills to become a STEM professional. The BBSP was created during a university undertaking to redesign the general education program as well as the core curricula for all disciplines. The BBSP leveraged two specific curricular efforts: expanding 
student learning of the STEM knowledge-base and aligning course content with desirable knowledge and skills for careers within students' discipline of study.

To better prepare students for the academic demands of college, the BBSP adopted proven practices in minority student achievement from K-12 classrooms: caring teachers, high expectations, a disciplined learning environment, academic rigor, and an active student learning environment (Somers, Owens, \& Piliawsky, 2008; Howard, 2001; LadsenBillings, 1994; Grantham \& Ford, 2003; Allison \& Rehm, 2006). In addition, a familial classroom environment was shown to significantly impact minority student academic success (Coats \& Xu, 2011; Booker, 2006; Howard, 2001). Familial bonds influenced habits and behaviors needed to survive and excel in the academic environment. Familial aspects, then, became the foundation of the BBSP.

To better prepare students as STEM professionals, the BBSP leveraged the STEM core curricula to train students on skills and knowledge-concepts expected of STEM professionals: problem solving skills, critical thinking skills, technology applications, leadership skills, teamwork, ethics, and career development (STEM Career Cluster, 2008). The BBSP also partnered with the Center for Student Opportunities, an academic support office on campus, to take advantage of its partnerships with national and local businesses and institutions. Research has shown that institutional partnerships with businesses and corporations provide resources that advance students along the pathway towards a professional career. Example opportunities include mentorships, internships, professional development workshops, financial contributions, as well as research and commercialization (Davis \& Binder, 2016; North, 2011; Madden, 2005). The Center for Student Opportunities provided tutoring, professional development workshops, internships, and graduate school visits. The BSSP incorporated these activities into its program design.

To further prepare students academically and professionally, the BBSP also adopted undergraduate research and faculty and peer mentoring as program components. Undergraduate research and mentoring are two widely recognized pedagogical movements in STEM that have greatly benefitted undergraduate minority students (Roach, 2015). Together, the above activities provided the framework of the BSSP. The development of a program with such unique characteristics prompted three broad research questions:

1. Would the incorporation of culturally relevant practices taken from a K-12 environment as well as the incorporation of a STEM workforce knowledge-base and skillset translate into a successful undergraduate STEM academic environment for underrepresented minority STEM majors?

2. Would this integrated, familial environment positively influence attitudes and interest to pursue graduate/professional study in STEM and/or a professional career in STEM?

3. Would adoption of such practices and environments translate into desirable outcomes such as improvements in retention rates, graduation rates, academic performance, and STEM career placements and advancements? 


\section{Literature Review}

The Role of Historically Black Colleges and Universities. Historically Black Colleges and Universities (HBCUs) play an integral role in contributing to national graduation and retention rates for African American students. Approximately $20 \%$ of African-American college students attend HBCUs (Aud et al., 2011). Moreover, 17 of the top 21 undergraduate producers of African-American STEM doctoral degrees were HBCUs (U.S. Commission on Civil Rights, 2010). Historically, HBCUs have higher retention and graduation rates for African American students than predominantly white institutions (PWIs). Literature has shown that HBCUs cultivate a more supportive learning environment for minority students than PWIs (Fleming, 1984; Allen, 1992). Davis (1994) concluded that the social and academic environments of HBCUs positively impacted minority students' self-esteem, academic proficiency, and social development all of which help to retain and matriculate students through academic programs. The National Council of Education Statistics (Aud et al., 2011) reported that HBCUs produced 21\% of all 4-year degrees awarded to African-Americans, and 28\% of STEM bachelor's degrees bestowed to African Americans (Lee \& Darity, 2012). Further, African American STEM students attending an HBCU enroll in graduate STEM programs in higher numbers than those who attend PWIs (Wenglinsky, 1997).

Research has cited that it is not a lack of interest in science that causes attrition in STEM, but rather, that educational disadvantages are cumulative in nature. Science builds on its content through grade levels and failures (of student learning, insufficiency of teaching, low school funding, etc.) can prevent students from mastering the prerequisite knowledge that they need to understand the content and continue to be motivated (Sasso, 2008). Minority students entering U.S. colleges demonstrate equal interest in STEM as their Caucasian peers, yet they are only two-thirds as likely as Caucasians to earn bachelor's degrees in those fields (Koenig, 2009). Attrition rates for African Americans are nearly twice as high as for Caucasians and Asians in STEM. Further, for African Americans, onethird of this attrition takes place within the first four semesters of college (Hewitt \& Seymour, 1991; Phillips, 1991).

The gap in bachelor's degree attainment between African Americans and their counterparts continues to persist (Beede et al., 2011). With regard to degree attainment, the 6-year graduation rates (of 120/130 credits) for all majors have remained stagnant around $50 \%$. However, within science and engineering fields, there have been signs of improvement- 63\% compared to 55\% in non-science and engineering fields (NSF, 2012). Nevertheless, Caucasians have earned twice as many science and engineering degrees than African Americans, and three times as many science and engineering degrees than Hispanics (Beede et al., 2011). As there is also a shortage of STEM minorities nationally, these findings provide additional emphasis on the role HBCUs have in contributing to higher rates of minorities earning STEM bachelor's degrees.

The STEM Family Model. The Benjamin Banneker Scholars Program (BBSP) was designed to address seven challenges for recruiting and retaining minority students (Nestor \& Kerka, 2009): 1) academic preparedness, 2) low self-efficacy, 3) assurance of belonging 
within the discipline, 4) environmental isolation, 5) financial support, 6) lack of supportive network, and 7) impractical expectations of themselves and their college experiences. Academically successful students often come from families with a strong parental education, higher parent incomes, and a strong family structure with active involvement from both parents in their cultural, social, and intellectual development. These families also have ties with educated and elite communities that further enrich their children's cognitive development from an early age. Unfortunately, such a supportive environment does not exist for many minority families of low income, having first-generation college students. Parents have to work multiple jobs sometimes to support their families and are not able to spend adequate time with children. The conceptual framework of the BBSP is comprised of a family model that provides a supportive environment to minority, first-generation college students. The model is aligned with proven practices from K-12 education and introduces parental guides who instill knowledge and skills essential to becoming academically successful. The parental guides, referred to from hereon as faculty mentors, replicate three important elements that typically define the role of a parent. The faculty mentors serve as (1) well-informed parents who are actively involved in a student's cognitive development, as well as the student's intellectual and emotional growth, (2) supportive parents who provide encouragement and advice about advanced education and professional careers, and (3) caring parents who are concerned about the student's health, wellness, and safety. The model also mimics the social environments prevailing in successful families which are comprised of activities that strengthen bonds within the family and activities that strengthen bonds within communities of academically successful individuals who may serve as additional role models. The framework when implemented would provide a stronger foundation to address the challenges faced by minority students.

Below are established multicultural practices from K-12 that created the STEM Family Model (STEM-FM). These practices, known as the pillars of BBSP, were:

Supportive "family" environment. By creating a familial atmosphere in the classroom, Booker (2006) reported that a sense of belonging was the most influential factor on student success for minority high school students. A study of elementary classrooms concluded that a familial atmosphere, where teachers displayed behaviors similar to the roles of mother, father, or elder relative, positively influenced minority students' social and psychological needs, increased students' self-esteem, technical confidence, and social skills (Howard, 2001).

Caring teachers. Research has shown that a positive correlation between minority students' perception of caring teachers who provided a strong supportive network and students' desire to learn from such a teacher fulfilled their inherent need for selfactualization. (Noddings, 1992; Ellis, 2008; Somers et al., 2008; Howard, 2001).

High expectations. Having high expectations of students in the classroom and supporting those expectations with multicultural pedagogy increased minority students' desire to meet those expectations (Ladson-Billings, 1994). Moreover, coupled with the ethic of caring, students' academic expectations of themselves also increased (Noddings, 1992).

Academic rigor. A 2006 middle school study by Allison and Rehm compared the impact of two learning environments - traditional vs. dynamic - had on minority students' 
academic performance with a new and more challenging mathematics curriculum. Results showed an increase in students' academic performance in the dynamic classroom, illustrating that it is the learning environment not the rigor of the curriculum that had the most impact on student success.

Dynamic classroom strategies. A study on gifted minority high school students concluded that students' academic achievement was increased by academic support activities such as role models, group meetings with faculty advisors, small academic communities, and professional development sessions (Grantham \& Ford, 2003).

Discipline. Two studies (Hill, 1995; Howard, 2001) found that minority students performed best in a structured classroom environment, where authority was clearly defined, and correction and order were conducted in a manner similar to students' home environments.

Mentoring. Mentoring had a positive impact on the academic performance of urban middle school male students. Among several aspects that contributed to their high grade point averages (GPA), emphasis on learning in an environment where their cultural strengths and pride were nurtured had the maximum effect. Other factors which should be given equal attention were attitudes towards their racial identity, and internalization and identification with academics (Gordon et al., 2009).

The STEM Workforce Knowledge Base and Skillset. To develop students into STEM professionals, proven skills and knowledge concepts that STEM professionals demonstrated were adapted within the core STEM curricula or added as separate program components to the BBSP (Advance CTE, 2008). These skills, known as the STEM Cluster Knowledge and Skills were:

Academic foundations. Achieving additional academic knowledge and skills required to pursue the full range of career and postsecondary education opportunities.

Communications. Using oral and written communication skills to express and interpret information and ideas including technical terminology and information.

Problem-solving and critical thinking. Solving problems using critical thinking skills (analyze, synthesize, and evaluate) independently and in teams. Solving problems using creativity and innovation.

Information technology applications. Using information technology tools to access, manage, integrate, and create information.

Systems. Understanding roles within teams, work units, departments, organizations, and inter-organizational systems and the larger environment. Identifying how key organizational systems affect organizational performance and the quality of products and services.

Leadership and teamwork. Using leadership and teamwork skills in collaborating with others to accomplish organizational goals and objectives.

Ethics and legal responsibilities. Knowing and understanding the importance of professional ethics and legal responsibilities.

Employability and career development. Knowing and understanding the importance of employability skills. Exploring, planning, and effectively managing a career. Knowing and understanding the importance of entrepreneurship skills. 


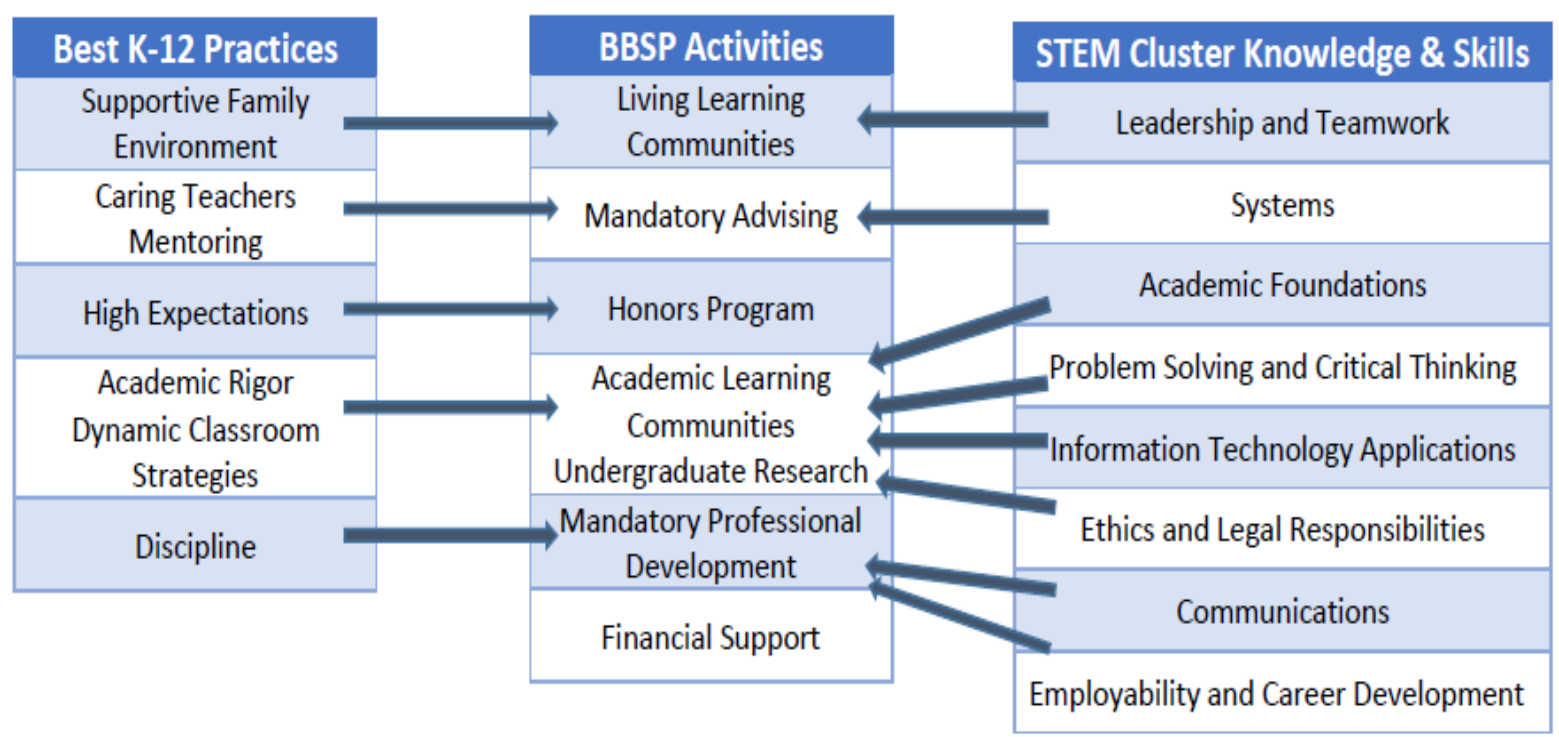

Figure 1. The Benjamin Banneker Scholars Program: A program informed by K-12 best practices for minority students and the STEM workforce knowledge-base and skillset.

The Benjamin Banneker Scholars Program. The K-12 pillars and STEM workforce skills informed components of the Benjamin Banneker Scholars Program, and in conjunction with an emphasis on undergraduate research, established the core of the BBSP (Figure 1).

The activities of BBSP were:

1. Scholars participated in a living, learning community by residing in the campus Honor's Dormitory (75\% of the Scholars shared a room with another scholar; $25 \%$ of Scholars were non-traditional students who lived off-campus). The Honor's Dormitory offered study areas, tutoring sessions, and peer-led study sessions. Scholars had easy access to peers taking (or peers who had taken) the same courses, and Scholars' academic habits and behaviors were adapted to a high-achieving learning environment.

2. The one-hour monthly mentoring meetings consisted of rituals, such as program announcements, student highlights, and a faculty advising session, that simulated a family gathering. During the advising session, faculty mentors, also known as Learning Community Coordinators (LCC), tracked student progress and provided advice for course registration, navigating college and/or the program discipline, study tips for STEM courses, and information and advice about research opportunities that aligned with student interests and STEM pursuits. Scholars and LCCs also formed smaller communities by major when they met at monthly meetings. These communities transcended beyond the monthly meetings. Shared family traditions (among LCCs and Scholars) included events like going out to eat and attending campus events together. The LCCs became family surrogates for student participants, which created a family atmosphere.

3. If qualified, Scholars were also encouraged to participate in the Honors Program. A 
3.2 GPA was required to participate, so this activity was optional. If Scholars participated, he/she received honors credit on their transcripts for coursework taken through the Honors Program.

4. Scholars participated in academic learning communities by taking at least two STEM courses with fellow Scholars each semester. As a result, Scholars formed study groups more easily and were more comfortable asking each other for help. In addition, per revised curriculum guidelines at the university, major courses within the program of study included a capstone and/or group project. Curriculum changes were set by national program committees for the discipline (i.e., Mathematics Association of America, American Chemical Society, Accreditation Board for Engineering and Technology) and approved by state committees within the Ohio Board of Regents. The capstone/group projects required problem solving (preferably using real-world examples), analytical and critical thinking, teamwork, use of technology to represent and explain phenomena, and communication skills.

5. Each year, BBSP required all Scholars to attend at least two professional development workshops and two graduate school visits offered through the Center for Student Opportunities (CSO), a campus student support program. The CSO provided academic support though professional development workshops, tutoring, internship placement, scholarships, and graduate/professional study prep. The professional development workshops focused on career skills such as resume writing, preparing for job interviews, GRE/GMAT test prep, speaking skills, presentation skills, dinner etiquette, etc. Transportation was provided to visit four to six graduate schools annually.

6. Scholars were required to apply to at least one summer STEM research experience every year. Undergraduate research experiences also were required components of some STEM curricula programs. Research opportunities were provided through Scholars' LCCs or the CSO. Some LCCs had research funding and supported interested undergraduates throughout the summers and academic years on various research projects. CSO had established partnerships with universities and local and national businesses. Examples included Los Alamos National Laboratory, the Air Force Research Laboratory, NASA Glenn Research Center, the Ohio Space Grant Consortium, Avatec Electronic Systems, Ohio Valley Waste Management, the University of Maryland-Baltimore County, the University of Dayton, and Wright State University. Scholars presented findings from their research internships at various regional and national STEM conferences.

Scholars also received financial support in the form of a renewing, merit-based scholarship as long as eligibility requirements and programmatic components were met. The scholarship covered full tuition, housing, books, and all other allowable fees for students up to $\$ 7,500$ per year.

\section{Method}

The Institution. Central State University (CSU), located in Wilberforce, $\mathrm{OH}$, is an undergraduate HBCU with a student population of 2,100. During this study, more than 95\% of the student body was African-American, and over 59\% lived below the poverty 
Table 1. BBSP Scholar Demographics

\begin{tabular}{|c|c|c|c|c|c|}
\hline Cohort & Year Recruited & Rank & Ethnicity & Gender & Majors \\
\hline $\begin{array}{l}\text { Cohort } 1 \\
(\mathrm{~N}=8)\end{array}$ & Spring 2009 & 8 Sophomores & 8 African-Americans & $\begin{array}{l}1 \text { Male; } \\
7 \text { Females }\end{array}$ & $\begin{array}{l}6 \text { Biology; } \\
1 \text { Chemistry; } \\
1 \text { Mathematics }\end{array}$ \\
\hline $\begin{array}{l}\text { Cohort } 2 \\
(\mathrm{~N}=13)\end{array}$ & Fall 2009 & $\begin{array}{l}2 \text { Juniors; } \\
3 \text { Sophomores; } \\
8 \text { Freshmen }\end{array}$ & $\begin{array}{l}12 \text { African-Americans; } \\
1 \text { Interracial }\end{array}$ & $\begin{array}{l}4 \text { Males; } \\
9 \text { Females }\end{array}$ & $\begin{array}{l}3 \text { Biology; } \\
2 \text { Chemistry; } \\
2 \text { Computer Science; } \\
6 \text { Engineering }\end{array}$ \\
\hline $\begin{array}{l}\text { Cohort } 3 \\
(\mathrm{~N}=2)\end{array}$ & Fall 2010 & $\begin{array}{l}1 \text { Sophomore; } \\
1 \text { Junior }\end{array}$ & 2 African-Americans & $\begin{array}{l}1 \text { Male; } \\
1 \text { Female }\end{array}$ & $\begin{array}{l}1 \text { Mathematics; } \\
1 \text { Engineering }\end{array}$ \\
\hline $\begin{array}{l}\text { Cohort } 4 \\
(\mathrm{~N}=7)\end{array}$ & Fall 2011 & 7 Sophomores & $\begin{array}{l}5 \text { African-American; } \\
1 \text { Caucasian; } \\
1 \text { Hispanic }\end{array}$ & $\begin{array}{l}5 \text { Males; } \\
2 \text { Females }\end{array}$ & $\begin{array}{l}3 \text { Biology; } \\
3 \text { Computer Science; } \\
1 \text { Engineering }\end{array}$ \\
\hline
\end{tabular}

Note. Total of 30 BBSP Scholars. For Fall 2012 and Fall 2013, no new Scholars were recruited, only continuing Scholars were supported for the 2012 -2013 and 2013-2014 academic years.

level. Eleven percent of the student body pursued a STEM degree in biology, chemistry, computer sciences, engineering, mathematics, or water resources management. The average entering ACT score for all CSU freshman was 16.27, and 18.18 for STEM students (Central State University Factbook, 2009, 2010, 2011, 2012, 2013, 2014).

Participants and Selection Criteria. The BBSP was advertised annually and eligible students applied for entry into the program's open slots (as determined by available scholarship dollars). Entrance into BBSP required a minimum 3.0 cumulative GPA, declaration as a STEM major, a statement of purpose, and letters of recommendation. BBSP required all participants to maintain a minimum 3.0 GPA. Scholars dropping below the 3.0 GPA were given one semester to restore eligibility or were dismissed from the program. Additional academic support (e.g., tutoring, counseling) was also provided by request, but was not mandatory. Failure to complete the required activities each year resulted in a reduction of a student's academic scholarship. Seven faculty served in two areas of BBSP: Principal Investigator (PI) and Learning Community Coordinators (LCCs); As LCCs, some faculty also served in additional capacity as Co-PIs. Over the duration of the program, a total of 30 students of various undergraduate ranks participated in the BBSP. Participant demographics are listed in Table 1.

Instrumentation. Given the robustness of this study, benchmarks gauging success were collected from both qualitative and quantitative sources. Below is a detailed summary of each survey instrument:

National Science Foundation Scholarships in Science, Technology, Engineering, and Mathematics Student Tracking System: Each year, Scholars' academic performances were recorded in the National Science Foundation (NSF) Scholarships in STEM Student 
Tracking System. The NSF required for five quantitative measures to be tracked for all scholarship recipients: (1) student GPA (major and cumulative), (2) internship/research placement, (3) success in entering the STEM workforce or further professional STEM study, (4) comparative retention rates to non-participants in STEM and at the institution, and (5) comparative graduation rates to non-participants in STEM and at the institution. These data were collected and reported electronically at the end of each semester.

Benjamin Banneker Scholars Program Scholar and Mentor Satisfaction Surveys: The BBSP conducted an annual satisfaction survey that documented the experiences and perceptions of Scholars and LCCs. The surveys included 20 items across four areas: (1) mentoring and advising, (2) program communication, (3) services and resources, and (4) group and individual activities. Seventeen questions were multiple choice (with a write-in option) and three questions were open-ended, short answer for respondents to share comments about their feelings and experiences. The surveys were conducted at the end of each academic year and administered to all participating scholars and LCCs active that year.

Science, Technology, Engineering, and Mathematics Student Comparison College Adjustment Survey: The adoption and use of the STEM Student Comparison College Adjustment Survey (CAS) stemmed from motivation of the BBSP staff to further understand student attitudes and academic experiences within a STEM major, and was only conducted in the last year of the program. The CAS was developed using questions from the CIRP First Year of College Survey and the Motivated Strategies for Learning Questionnaire. The CAS survey was administered to Benjamin Banneker Scholars and non-participating STEM students. Metrics measuring attitudes and perceptions of college experiences were captured. All indicator items were measured on a 5-point Likert scale (Two examples include, 1-Not at All to 5-A Great Extent, and 1-Strongly Disagree to 5Strongly Agree).

Procedures. For quantitative measures collected from the NSF-Scholarships in STEM Student Tracking System, comparative graduation and retention rates were calculated for BB Scholars, all STEM majors, and all university students. Through student academic performance reports generated by the Office of Assessment and Institutional Research, major and cumulative mean GPAs were also computed. The number of internship placements and admission/enrollments in graduate or professional STEM study or employment in a STEM career were also tracked.

The annual scholar and mentor satisfaction surveys were anonymous and response rates were $100 \%$ each year. To analyze the phenomenological data collected, pattern analysis was used to identify common themes about student and staff perceptions of project implementation, project activities, and program components. Reoccurring language (words, phrases, and context) across each survey item was recorded and deduced as themes.

Lastly, the CAS surveyed BB Scholars and non-participating STEM peers. The CAS was administered to the peer group $(\mathrm{N}=63)$ on a voluntary basis. Students enrolled in Computer Science ( $\mathrm{N}=19$, response rate $53 \%)$, Algebraic Structures $(\mathrm{N}=6$, response rate $16.7 \%)$, Calculus I ( $\mathrm{N}=26$, response rate $65 \%$ ), Calculus II $(\mathrm{N}=20$, response rate $80 \%)$, Trigonometry ( $\mathrm{N}=10$, response rate $60 \%)$, Biology Seminar $(\mathrm{N}=10$, response rate $90 \%$ ), 
Table 2. BBSP Student Profiles vs. CSU STEM Student Profiles: 2008 - 2013

\begin{tabular}{lllllll}
\hline Academic Measures & & BBSP & & \multicolumn{3}{c}{ CSU STEM } \\
& $M(S D)$ & Min & Max & $M(S D)$ & Min & Max \\
\hline ACT Score & $20.00(2.88)$ & 16.00 & 25.00 & $18.29(3.13)$ & 13.00 & 27.00 \\
HS GPA & $3.14(0.58)$ & 2.17 & 3.81 & $2.92(0.61)$ & 1.73 & 3.97 \\
Cumulative GPA & $3.32(0.40)$ & 2.79 & 4.00 & $2.83(0.54)$ & 1.50 & 4.00 \\
Major GPA & $3.46(0.40)$ & 2.75 & 4.00 & $2.78(0.81)$ & 2.00 & 4.00 \\
\hline
\end{tabular}

Molecular Cell Biology N=7, (response rate 71\%) and Bioinformatics ( $\mathrm{N}=7$, response rate $100 \%$ ) were encouraged to complete the survey and took the survey electronically to track single participation in the survey. At the time the survey was conducted 11 BBSP students participated (response rate of 100\%). To analyze collected data, confirmatory factor analysis was used to determine satisfactory item loadings for final scales. Cronbach's alpha $(\alpha)$ was used to measure internal consistency for each scale, and mean composite scores were computed for each scale. Further, ANOVA tests were performed to assess for statistical differences among groups across each scale.

Data Analysis. To answer the first research question about the success of the STEM learning environment created by the BBSP, we highlight student perceptions of the integrated STEM environment and its impact on students' academic performance, specifically GPA, undergraduate research, and retention and graduation rates. To answer our second research question about student attitudes and continued interests in STEM careers and/or professional study, we highlight the degree to which students perceived their ability to cope with the demands of being a STEM major. The CAS identified nine factors that influenced how students altered their approach to life events at college. Higher mean scores of each factor implied higher functionality, flexibility, and coping process management with the academic and social demands of college which undergirded students' preparedness and perceived readiness for professional careers and/or continued study in STEM. Lastly, to answer the third research question about whether the BBSP would yield desirable outcomes to improve retention and graduation rates, academic performance, and STEM career placements, we tracked and compared major and cumulative mean GPA, graduation rates retention rates, internship placements, and enrollment into graduate study/professional programs for BB Scholars, STEM majors, and, when appropriate, university students.

\section{Results}

To address the study's research questions, success for BBSP was based upon student academic performance, persistence towards a STEM career or advanced education upon graduation, and student and faculty mentor perceptions of programmatic components. These findings were observed across the following: 
Journal of Research in Technical Careers

Table 3. Scholar Perceptions of Mentoring

\begin{tabular}{|c|c|c|c|c|c|c|c|c|c|}
\hline \multirow{2}{*}{$\begin{array}{l}\text { Survey Item } \\
\text { (1-Strongly Disagree to 5- Strongly Agree) }\end{array}$} & \multicolumn{3}{|c|}{$\underline{2010-11}$} & \multicolumn{3}{|c|}{ 2011-12 } & \multicolumn{3}{|c|}{ 2012-13 } \\
\hline & Mean & SD & $\mathrm{N}$ & Mean & SD & $\mathrm{N}$ & Mean & SD & $\mathrm{N}$ \\
\hline $\begin{array}{l}\text { My faculty mentor was available when I } \\
\text { needed him/her. }\end{array}$ & 4.25 & 0.86 & 16 & 4.69 & 0.48 & 16 & 4.73 & 0.47 & 11 \\
\hline $\begin{array}{l}\text { My faculty mentor provided information } \\
\text { about research opportunities. }\end{array}$ & 4.31 & 0.95 & 16 & 4.69 & 0.60 & 16 & 4.45 & 0.93 & 11 \\
\hline $\begin{array}{l}\text { My faculty mentor was helpful in answering } \\
\text { questions. }\end{array}$ & 4.63 & 0.62 & 16 & 4.69 & 0.60 & 16 & 4.68 & 0.46 & 11 \\
\hline $\begin{array}{l}\text { My faculty mentor provided adequate } \\
\text { support to facilitate learning. }\end{array}$ & 4.56 & 0.63 & 16 & 4.63 & 0.62 & 16 & 4.68 & 0.46 & 11 \\
\hline $\begin{array}{l}\text { My faculty mentor provided constructive } \\
\text { feedback throughout the year. }\end{array}$ & 4.63 & 0.72 & 16 & 4.63 & 0.62 & 16 & 4.59 & 0.49 & 11 \\
\hline $\begin{array}{l}\text { My faculty mentor provided guidance about } \\
\text { my educational program. }\end{array}$ & 4.63 & 0.62 & 16 & 4.63 & 0.62 & 16 & 4.64 & 0.50 & 11 \\
\hline $\begin{array}{l}\text { My faculty mentor showed genuine concern } \\
\text { for me and treated me with respect. }\end{array}$ & 4.69 & 0.60 & 16 & 4.63 & 0.62 & 16 & 4.82 & 0.40 & 11 \\
\hline $\begin{array}{l}\text { My faculty mentor provided information } \\
\text { about internship opportunities. }\end{array}$ & 4.50 & 0.63 & 16 & 4.56 & 0.63 & 16 & 4.55 & 0.93 & 11 \\
\hline $\begin{array}{l}\text { My faculty mentor advised me about degree } \\
\text { progress. }\end{array}$ & 4.63 & 0.62 & 16 & 4.56 & 0.63 & 16 & 4.50 & 0.67 & 11 \\
\hline $\begin{array}{l}\text { My faculty mentor helped minimize my } \\
\text { anxieties about school? }\end{array}$ & 4.13 & 1.02 & 16 & 4.50 & 0.63 & 16 & 4.36 & 0.81 & 11 \\
\hline $\begin{array}{l}\text { My faculty mentor provided information } \\
\text { about graduate school. }\end{array}$ & 4.38 & 0.81 & 16 & 4.44 & 0.63 & 16 & 4.50 & 0.92 & 11 \\
\hline $\begin{array}{l}\text { My faculty mentor provided information } \\
\text { about professional development workshops. }\end{array}$ & 4.31 & 0.95 & 16 & 4.25 & 0.68 & 16 & 4.45 & 0.93 & 11 \\
\hline Total Mentoring Composite Score* & 4.47 & 0.56 & 16 & 4.57 & 0.51 & 16 & 4.58 & 0.59 & 11 \\
\hline
\end{tabular}

*Total Mentoring Composite Score is the average of all twelve survey items.

Note. Reprinted from "National Science Foundation Benjamin Banneker Scholars Program at Central State

University Evaluation Report,” by R. Taylor, 2013.

Science, Technology, Engineering, and Mathematics Student Retention (corresponds to research questions 1 and 3). Over the 5-year period, the retention rate within BBSP was 88\% compared against 39\% for all other STEM students. One of the goals of BBSP was to assure that $80 \%$ of Scholars would receive continuing scholarships in subsequent years based upon satisfactory GPA and the completion of program requirements. From 2009-2013, the retention rates of continuing Scholars were 87.5\%, $77 \%, 86 \%$, 94\%, and 94\%, respectively. BBSP also tracked the retention rates within program disciplines, including those disciplines of former participants - those students who were inactive from BBSP but remained at CSU. (Four students left BBSP, including one student who also left the institution.). The retention of continuing students in a STEM major from 2009-2013 was 100\%, 90\%, 82\%, 100\%, and 94\%, respectively.

Graduation and Science, Technology, Engineering, and Mathematics Placement (corresponds to questions 1 and 3). At the end of the BBSP, 93\% of the BB Scholars graduated. One scholar had completed a STEM masters, six were in STEM master 
Table 4. Faculty Perceptions of Mentoring

\begin{tabular}{|c|c|c|c|c|c|c|c|c|c|}
\hline \multirow{2}{*}{$\begin{array}{l}\text { Survey Item } \\
\text { (1- Strongly Disagree to 5- Strongly Agree) }\end{array}$} & \multicolumn{3}{|c|}{$\underline{2010-11}$} & \multicolumn{3}{|c|}{$\underline{2011-12}$} & \multicolumn{3}{|c|}{$\underline{2012-13}$} \\
\hline & Mean & SD & $\mathrm{N}$ & Mean & SD & $\mathrm{N}$ & Mean & SD & $\mathrm{N}$ \\
\hline I am genuinely concerned for the scholars. & 5.00 & 0.00 & 6 & 5.00 & 0.00 & 5 & 5.00 & 0.00 & 5 \\
\hline I advised scholars about degree progress. & 5.00 & 0.00 & 6 & 5.00 & 0.00 & 5 & 4.60 & 0.55 & 5 \\
\hline As a faculty mentor I am available when my & & & & & & & & & \\
\hline $\begin{array}{l}\text { mentees need me. } \\
\text { As a faculty mentor I am helpful in answering }\end{array}$ & 4.83 & 0.41 & 6 & 4.80 & 0.45 & 5 & 4.60 & 0.55 & 5 \\
\hline mentees' questions. & 4.83 & 0.41 & 6 & 4.80 & 0.45 & 5 & 4.80 & 0.45 & 5 \\
\hline $\begin{array}{l}\text { I provided information about graduate school } \\
\text { to the scholars. }\end{array}$ & 4.83 & 0.41 & 6 & 4.60 & 0.55 & 5 & 4.60 & 0.55 & 5 \\
\hline $\begin{array}{l}\text { I provided information about internship } \\
\text { opportunities to the scholars. } \\
\text { I provided information about research }\end{array}$ & 4.83 & 0.41 & 6 & 4.60 & 0.55 & 5 & 4.80 & 0.45 & 5 \\
\hline opportunities to the scholars. & 4.50 & 1.22 & 6 & 4.60 & 0.55 & 5 & 4.60 & 0.89 & 5 \\
\hline the semester. & 4.83 & 0.41 & 6 & 4.40 & 0.55 & 5 & 4.80 & 0.45 & 5 \\
\hline $\begin{array}{l}\text { As a faculty mentor I believe I have been able } \\
\text { to help minimize scholars' anxieties about } \\
\text { school. }\end{array}$ & 4.17 & 0.41 & 6 & 4.40 & 0.55 & 5 & 4.00 & 0.71 & 5 \\
\hline $\begin{array}{l}\text { I provided guidance about educational } \\
\text { programs. }\end{array}$ & 4.67 & 0.52 & 6 & 4.40 & 0.89 & 5 & 4.60 & 0.55 & 5 \\
\hline $\begin{array}{l}\text { I provide adequate support to facilitate } \\
\text { scholars' learning. }\end{array}$ & 4.67 & 0.52 & 6 & 4.20 & 0.84 & 5 & 4.40 & 0.89 & 5 \\
\hline $\begin{array}{l}\text { I provided information about professional } \\
\text { development workshops to the scholars. }\end{array}$ & 3.50 & 1.22 & 6 & 4.00 & 0.71 & 5 & 3.60 & 1.14 & 5 \\
\hline
\end{tabular}

Note. Reprinted from "National Science Foundation Benjamin Banneker Scholars Program at Central State University Evaluation Report,” by R. Taylor, 2013.

programs and three were pursuing STEM doctoral degrees. An additional five were in STEM workforce positions. The average graduation rate for non-BBSP STEM majors over the same period was $20 \%$. Of the non-BBSP cohorts in the same five-year period, 12 STEM students entered advanced STEM study and two had entered the STEM workforce.

Student Academic Achievement (corresponds to research questions 1 and 3). BBSP participation had positive impacts on student academic achievement. Scholars demonstrated improved academic performance, as evidenced in both major and cumulative GPAs, compared against other STEM students as demonstrated in Table 2.

Scholars were also significantly more active in undergraduate research, both on campus and summer internships. Sixty percent of BBSP Scholars participated and presented their research at local and/or national scientific conferences versus less than $16 \%$ of the comparison group. BBSP Scholars also produced 6 research publications during this same period while non-BBSP students produced none.

Undergraduate Research and Grade Point Average (corresponds to research questions 1 and 3). For Benjamin Banneker Scholars, there was a strong relationship 
Table 5. College Adjustment Survey Demographics

\begin{tabular}{lllll}
\hline & \multicolumn{2}{l}{ BB Scholars } & \multicolumn{2}{l}{ STEM Comparison } \\
\cline { 2 - 5 } & $N$ & $\%$ & 63 & $57.8 \%$ \\
\hline Total & 11 & $10.1 \%$ & & \\
$\quad$ Sex & & & 39 & $61.9 \%$ \\
$\quad$ Female & 5 & $45.5 \%$ & 22 & $34.9 \%$ \\
$\quad$ Male & 6 & $54.5 \%$ & & \\
Race & & & 56 & $88.9 \%$ \\
$\quad$ Black & 8 & $72.7 \%$ & 1 & $1.6 \%$ \\
Hispanic & 0 & $0.0 \%$ & 1 & $1.6 \%$ \\
Nat. Am. & 0 & $0.0 \%$ & 1 & $1.6 \%$ \\
White & 1 & $9.1 \%$ & 1 & $1.6 \%$ \\
Multi & 0 & $0.0 \%$ & 3 & $4.8 \%$ \\
$\quad$ Unknown/Not reported & 2 & $18.2 \%$ & & \\
Major & & & 37 & $60.7 \%$ \\
$\quad$ Sciences & 4 & $36.4 \%$ & 8 & $13.1 \%$ \\
Technology & 4 & $36.4 \%$ & 7 & $11.5 \%$ \\
Engineering & 3 & $27.3 \%$ & 5 & $8.2 \%$ \\
$\quad$ Mathematics & 0 & $0.0 \%$ & 4 & $6.6 \%$ \\
Education & 0 & $0.0 \%$ & 0 & $0.0 \%$ \\
$\quad$ Other & 0 & $0.0 \%$ & & \\
\hline
\end{tabular}

*Two students included in the STEM comparison group either did not provide an ID number or did not provide an adequate number to merge data with institutional research data. Data represented in the table above reflects the most recent data institutional research had on students during summer 2013.

Note. Reprinted from "National Science Foundation Benjamin Banneker Scholars Program at Central State University Evaluation Report,” by R. Taylor, 2013.

between cumulative GPA, major GPA and internship experiences. Scholars who did not have a summer internship experience had an average cumulative GPA of $2.94 \pm 0.26$ and a major GPA of $2.89 \pm 0.43$. Scholars having one internship experience had an average cumulative GPA of $3.21 \pm 0.06$ and a major GPA of $3.18 \pm 0.07$. Scholars having two summer internships had an average cumulative GPA of $3.54 \pm 0.23$ and a major GPA of $3.60 \pm 0.37$. Scholars having three summer internships had an average cumulative GPA of $3.76 \pm 0.28$ and a major GPA of $3.87 \pm 0.12$.

Mentoring/Advising (corresponds to research questions 1 and 2). Responses from an annual-satisfaction survey in 2009 indicated a strong perception of the effectiveness faculty mentoring played in the success of the BBSP. In response, students were asked additional questions on the frequency with which they met with their mentors beginning with the 2010 survey instrument to examine these perceptions more closely.

Survey results from 2010 and 2011 described interactions at 37\% with an increase to $64 \%$ in 2013. When asked to detail subjects discussed with the Scholars, faculty mentors listed grades, course difficulties and curriculum advising, internship opportunities, research, time management and study skills, preparation for graduate school and personal issues negatively impacting academic progress (Kendricks, Nedunuri, \& Arment, 2013).

The effectiveness of faculty mentoring was evaluated using student surveys. The 
Table 6. College Adjustment Survey Results: Attitudes \& Experiences

\begin{tabular}{|c|c|c|c|c|c|c|c|c|c|}
\hline \multirow[b]{2}{*}{ Factor } & \multicolumn{3}{|c|}{ BB Scholars } & \multicolumn{3}{|c|}{ Other STEM } & \multirow[b]{2}{*}{$F$} & \multirow[b]{2}{*}{$p$} & \multirow[b]{2}{*}{$\eta 2$} \\
\hline & $M$ & $S D$ & $N$ & $M$ & $S D$ & $N$ & & & \\
\hline Peer Learning & 4.25 & 0.77 & 11 & 3.60 & 0.94 & 63 & 4.80 & 0.032 & 0.063 \\
\hline Help Seeking of Faculty & 4.31 & 0.61 & 11 & 3.77 & 0.88 & 63 & 3.73 & 0.057 & 0.049 \\
\hline Expectations of Faculty & 3.14 & 1.32 & 11 & 3.06 & 1.19 & 63 & 0.04 & 0.839 & 0.001 \\
\hline Self-Efficacy & 3.49 & 1.06 & 11 & 3.45 & 0.94 & 63 & 0.02 & 0.903 & 0.000 \\
\hline Critical Thinking Skills & 4.04 & 0.57 & 11 & 3.59 & 0.79 & 63 & 3.19 & 0.078 & 0.042 \\
\hline Metacognitive Self-Regulation & 4.30 & 0.46 & 11 & 4.03 & 0.60 & 63 & 1.99 & 0.163 & 0.027 \\
\hline Organization & 3.59 & 0.94 & 11 & 3.53 & 1.00 & 63 & 0.04 & 0.846 & 0.001 \\
\hline Task Value & 3.03 & 1.19 & 11 & 3.17 & 1.06 & 63 & 0.17 & 0.682 & 0.002 \\
\hline Effort Regulation* & 3.82 & 1.19 & 11 & 3.49 & 1.18 & 58 & 0.72 & 0.398 & 0.011 \\
\hline
\end{tabular}

*Items used to indicate effort regulation were reverse coded in order to interpret measures on these scales using the continuum 1 to 5 with 5 being the most favorable.

Note. Reprinted from "National Science Foundation Benjamin Banneker Scholars Program at Central State University Evaluation Report,” by R. Taylor, 2013.

survey was conducted from 2010 - 2013. Both Scholars and mentors were asked twelve similar questions based on a 1-5 Likert scale ranging from 1 - Strongly Disagree to 5 Strongly Agree. Findings are reproduced in Tables 3 and 4.

Table 3 also includes a Total Mentoring Composite (TMC) score, computed by averaging all twelve items for both students and faculty. TMC shows a high overall approval rating of 4.4 or above. The reliability of this mentoring score using Cronbach's alpha was 0.962 for students and 0.915 for faculty.

Overall, both Scholar and faculty responses to each question on positive aspects of mentoring received high approval ratings from both stakeholder groups. Scholar perceptions on most of survey questions on mentoring received steady approval ratings above 4.5 over the three-year period. Scholars' perceptions of faculty mentor's availability increased from 4.25 in 2010-2011 to 4.73 in 2012-2013. Their perception on facilitation to learning by their mentors also increased from 4.56 in 2010-2011 to 4.68 in 2012-2013.

Comparison of Student Attitudes and Experiences (corresponds to research question 2). At the time the College Adjustment Survey was administered there were 11 active Benjamin Banneker Scholars. Inclusive of Scholars, a total of 74 students (STEM and non-STEM) completed the CAS. Participant demographics are displayed in Table 5.

Table 6 demonstrates that student perceptions (STEM vs. non-STEM) varied most widely in the areas of Peer Learning, Help Seeking of Faculty, Critical Thinking Skills, Metacognitive Self-Regulation, and Effort Regulation. Table 6 shows the results of conducting Confirmatory Factor Analysis of satisfactory items perceived by STEM students (BBSP and non-BBSP): Peer Learning $(\alpha=.485)$, Help Seeking from faculty $(\alpha=.807)$, Faculty Support $(\alpha=.729)$, Self-Efficacy $(\alpha=.746)$, Task Value $(\alpha=.653)$, Organization Strategies $(\alpha=.714)$, Critical Thinking $(\alpha=.778)$, Metacognitive SelfRegulation $(\alpha=.850)$, and Effort Regulation $(\alpha=.407)$.

ANOVA tests provided evidence of strong differences between the comparison groups. 
The mean scores are more positive for Scholars than the mean scores for the STEM comparison students across all scales except Task Value (Table 6).

In some instances, survey items did not load well together, or reliability scores between items were too low to group items together. For example, one item was asked according to frequency ("How Often Did You... come to class late, or turn assignments in late, work on- or off-campus ...”). Scholars exhibited favorable frequencies (exhibiting such behaviors less often). In general, lower scores would have been more desirable for additional analyses.

\section{Discussion}

The challenges of increasing diversity in the STEM workforce begin with providing a strong, steady stream of prepared students with the ability to matriculate undergraduate programs. Retention of a diverse student demographic is key to achieving success. Retention and graduation are further complicated when the target demographic enters from an academically unprepared environment into an area demanding high academic preparation.

At the institutional level, HBCUs are well suited in providing an overall nurturing academic, psychological and social environment where underprepared students adapt and grow into STEM professionals. At the programmatic level, models such as the STEM-FM provide an additional level of support that better meets the needs of students whose success depends on forging connections with faculty.

Our findings on the importance of family and faculty interactions in supporting African Americans in STEM from the CAS are echoed in the literature. Hurtado et al. (2011) reported that the positive impacts that HBCU faculty have are based upon the frequency and depth of faculty-student interactions. BBSP Scholars gave high approval ratings to faculty mentoring through surveys. In past work, Kendricks et al. (2013) discussed the academic and personal benefits of intrusive mentoring and advising and how these resulted in greater efficiency by adopting K-12 best practices. The practice of creating a family environment led to the promotion of strong supportive networks and increased both retention rates and academic performances. These findings are supported by the research of others (Guiffrida, 2005; Slaughter-Defoe et al, 2006; Griffin \& Toldson, 2012).

Given national concerns over undergraduate attrition and retention rates in STEM for all groups, including African Americans, the results of BBSP demonstrated retention of participating students at more than twice the rate of non-participants. Similarly, graduation rates were significantly enhanced for program participants. BBSP Scholars were six times more likely to graduate compared to non-BBSP participants.

The building of living, learning communities and academic learning communities provided collaborative environments of learning and a sense of belonging among students and faculty mentors. The safety of this environment allowed gaps in STEM knowledge, proficiencies, and skills to be bridged in a non-threatening and nurturing environment. Further, the social development of leadership and teamwork contributed towards future success.

Transition into advanced STEM study and the professional STEM workforce were, 
likewise, enhanced. BBSP Scholars were nearly three times as likely to continue career pathways in STEM as their peers. BBSP academic learning communities also addressed the critical challenge of impractical expectations that stem from under preparedness when entering STEM college programs.

The impacts on academic performance were demonstrated in both cumulative GPA and in major GPA when comparing BBSP Scholars to their peers. Two major findings of the CAS were the greater emphasis BBSP Scholars placed on critical thinking skills and metacognitive self-regulation. We believe these perceptions carried through in the observations of increased academic performance. The Honors program allowed participants to work on additional projects within a designated course and write reports that may have also contributed to the enhancement of these skills.

When these results were compared against the value added from undergraduate research experiences, the results became even more pronounced. BBSP undergraduate research addressed and removed the challenges of lack of self-efficacy and self-esteem among STEM students and harnessed their self-actualized need to achieve and excel in their disciplines and careers.

Emphasis on the value of undergraduate research in BBSP as part of the training process of becoming a scientist or an engineer cannot be overstated. The benefits of undergraduate research, particularly among minority students in student success, and retention and graduation rates has been well documented in the literature. Overall, any student participating in undergraduate research demonstrates a $26 \%$ greater chance of attending graduate school or professional programs; this number was $21.9 \%$ specifically for minority students (Nagda et al., 1998; Hathaway et al., 2002; Seymour et al., 2004; Taraban \& Blanton, 2008; Carter et al., 2009; Jones et al., 2010).

Professional development offered through graduate school visits, internship opportunities, workshops and test preparation provided participants with career goals and aspirations in their respective disciplines. These may have contributed to their retention and graduation. An average score of 4.4 given by the students on the survey item "My faculty mentor provided information about graduate school opportunities and a 4.54 given on the item "My faculty mentor provided information on professional development workshops" suggests a strong influence of engaging student participants on several professional development activities. Our own findings reveal that STEM-FM model may serve as a framework for creating "an environment of survival followed by success" among low income, first generation, minority students who have been academically unprepared for rigorous STEM disciplines in college.

Limitations. The authors acknowledge the study's design possessed limitations. First, to participate in the BBSP, students were required to have a 3.0 high school GPA. However, it should be pointed out that not all Scholars with high GPA had taken one year of advanced placement chemistry or physics, or two years of mathematics leading up to pre-calculus in high school, which is typically expected of high school students entering into science and engineering programs. It can be argued that students earning a high school GPA of 3.0 or above were already academically prepared and embodied the characteristics and study skills to ensure their academic success. The authors were aware that the program 
participants were high achieving students, however, the program's GPA requirements were limited to the merit-based scholarship specifications set forth by the funding agency. The findings demonstrate that even for students with a propensity for academic achievement, their successes, skills, and competencies can be further enhanced (or retained) by attributes of the Scholars' program. It is also our opinion that BBSP activities contributed to sustaining a high GPA for the Scholars. A more robust study should examine the effects of this program on the academic performance and persistence of STEM majors earning a 2.53.0 GPA.

Second, the population of the study group was small; only 13\% (30 students) of STEM majors participated in the BBSP. It would have enhanced the study if a larger sample size of eligible students was used. Unfortunately, the number of participants was limited each year by the availability of scholarship funds.

Lastly, this study capitalized on an ongoing institutional initiative to (1) align the general education curriculum with the curriculum of a local K-12 system and (2) to (re)design course and degree program content to better equip students for careers that stem from their discipline of study. This two-pronged initiative was the backdrop for establishing the BBSP. It provided campus-wide investment in revamping the curricula and created faculty energy to integrate new and innovative ideas, producing a welcoming environment to introduce new and complementary approaches to academic support. The uniqueness of the campus landscape does not go unnoticed. Similar initiatives were ongoing in other states, such as Texas and Arizona. The goal for anyone seeking to model the Scholars program at his/her institution would be to examine the campus culture and climate, and learn about administrative-led initiatives to add onto to build momentum, support, and advocacy to introduce new and complementary ideas.

\section{Conclusions}

Culturally responsive practices for African American students have proven to be a successful strategy for academic success in K-12 education. Taken as a whole, the performance of the Benjamin Banneker Scholars suggests that lessons learned from K-12 best practices can be successfully applied to undergraduate STEM majors. Further, incorporating skills and abilities that align with employers' needs better prepares Scholars for careers in a STEM field. The combination of peer support, faculty mentoring, professional development and encouraged undergraduate research successfully transitioned students towards the increasing responsibilities of advanced study in STEM and careers in the STEM workplace. The creation of a familial environment that is supportive of students' social and academic needs translated as a successful vehicle for grooming professional behaviors and academic habits that positively affected undergraduate academic performance and continued persistence in STEM careers.

Can the best practices of BBSP be given broader application to other institutions and to what degree? The limiting factor in any attempt to "scale up" these practices is the degree to which the nurturing environment can be maintained. Whether it be an institution-wide setting, a programmatic or departmental one, or a pocket of students within a large, traditional institution, it is our extended opinion that students will respond if strong faculty- 
student interpersonal interactions can be forged and maintained in the context of the best practices presented here.

Note: Funding for this study was provided by the National Science Foundation's Division for Undergraduate Education (DUE\#0806741). The authors would like to thank Dr. Robin Taylor for providing program evaluation as well as the many reviewers of this manuscript for their suggestions for continued improvement.

\section{References}

Adelman, C., Ewell, P., Gaston, P., Schneider, C. (2014). The degree qualifications profile: A learning-centered framework for what college graduates should know and be able to do to earn the associate, bachelor's or master's degree. Retrieved from https://www.luminafoundation.org/files/resources/dqp-web-download.pdf

Advance CTE. (2008). Science, technology, engineering and mathematics career cluster knowledge and skill statements. Retrieved from https://cte.careertech.org/sites/default/files/K\%26S-CareerCluster-ST-2008.pdf

American College Testing. (2016). The condition of college and career readiness. Retrieved from https://www.act.org/content/dam/act/unsecured/documents/CCCR_National_2016.pdf

Allen, W. R. (1992). The color of success: African-American college student outcomes at predominantly white and historically black public colleges and universities. Harvard Educational Review, (62), 26-44.

Allison, B. N., \& Rehm, M.L. (2006). Meeting the needs of culturally diverse learners in family and consumer sciences middle school classrooms. Journal of Family and Consumer Sciences Education, 24(1), 50-63.

Aud, S., Hussar, W., Kena, G., Bianco, K., Frohlich, L., Kemp, J., \& Tahan, K. (2011). The condition of education 2011 (NCES 2011-033). U.S. Department of Education, National Center for Education Statistics. Washington, DC: U.S. Government Printing Office.

Beede, D., Julian, T., Khan, B., Lehrman, R., McKittrick, G., Langdon, D., \& Doms, M. (2011). Education supports racial and ethnic equality in STEM. US Department of Commerce, Economics and Statistics Administration, ESA Issue Brief \#05. Retrieved from https://files.eric.ed.gov/fulltext/ED523768.pdf

Booker, K. C. (2006). School belonging and the African-American adolescent: What do we know and where should we go? The High School Journal, 89(4), 1-7. https://doi.org/10.1353/hsj.2006.0005

Carnevale, A. \& Rose, S. (2011). The undereducated American. Washington, DC: Georgetown University Center on Education and the Workforce. Retrieved from https://1gyhoq479ufd3yna29x7ubjn-wpengine.netdna-ssl.com/wpcontent/uploads/2014/11/undereducatedamerican.pdf

Carnevale, A., \& Smith, N. (2013). Workplace basics: The skills employees need and employers want. Human Resource Development International, 16(5), 491-501.

Coats, L. \& Xu, J. (2011). No Child Left Behind and outreach to families and communities: The perspectives of exemplary African-American science teachers. Journal for Research in Education, 28(5), 609-627.

Complete College OHIO Task Force. (2011). Task force (and subcommittee) reports and recommendations. University System of OHIO Board of Regents.

Complete College OHIO Task Force. (2014). Task force (and subcommittee) reports and 
recommendations. University System of OHIO Board of Regents.

Conley, D. \& Gaston, P. (2013). A path to alignment: Connecting K-12 and higher education via the common core and the degree qualifications profile. Lumina Foundation: Indianapolis, IN.

Davis, D. \& Binder, A. (2016). Selling students: The rise of corporate partnership programs in university career centers. Research in the Sociology of Organizations, 46, 395-422

Davis, J. (1994). College in black and white: Campus environment and academic achievement of African American males. The Journal of Negro Education, 63(4), 620-633. https://doi.org/10.1177/0095798400026002002

Ellis, T.D. (2008). Lessons from the gap closers: The middle school philosophy in urban schools. North Carolina Middle School Association Journal, 23(1), 1-8.

Fleming, J. (1984). Blacks in college: A comparative study of student success in black and white institutions. San Francisco, CA: Jossey-Bass.

Grantham, T. C. \& Ford, D. Y. (2003). Beyond self-concept and self-esteem: Racial identity and gifted African-American students. The High School Journal, 87(1), 18-29. https://doi.org/10.1353/hsj.2003.0016

Griffin, K.A., Toldson, I.A. (2012). Reflections on mentoring for blacks in academia. The Journal of Negro Education, 81(2), 103-105.

Gordon, D.M., Iwamoto D.K., Ward N., Potts R., \& Boyd, E. (2009). Mentoring urban black middle school male students: Implications for academic achievement. The Journal of Negro Education, 78(30), 277-289.

Guiffrida, D. (2005). Othermothering as a framework for understanding African American students' definitions of student-centered faculty. The Journal of Higher Education, 76, 701723. https://doi.org/10.1353/jhe.2005.0041

Hathaway, R.S., Nagda, B. A., \& Gregerman, S. R. (2002). The relationship of undergraduate research participation to graduate and professional educational pursuit: an empirical study. Journal of College Student Development, 43:614-631. https://doi.org/10.1187/cbe.10-10-0130

Hewitt, N. M., \& Seymour, E. (1991). Factors contributing to high attrition rates among science, mathematics, and engineering undergraduate majors. Report to the Alfred P. Sloan Foundation. Boulder, CO: Bureau of Sociological Research, University of Colorado.

Hill, H. E. (1995). The relationship between family environment and parenting style: A preliminary study of African American families. Journal of Black Psychology, 21(4), 408423. https://doi.org/10.1177/00957984950214007

Howard, T. C. (2001). Telling their side of the story: African-American students' perceptions of culturally relevant teaching. The Urban Review Journal, 33(2), 131-149. https://doi.org/10.1023/A:1010393224120

Hurtudo, S., Eagen, M. K., Tran, M. C., Newman, C. B., Chang M. J., \& Velasco, P. (2011). “We do science here": Underrepresented students' interactions with faculty in different college contexts. Journal of Social Issues, 76(3), 553-579. https://doi.org/10.1111/j.15404560.2011.0714.x

Jankowski, N., \& Marshall, D. (2015). Degree Qualifications Profile (DQP) and Tuning: What are they and why do the matter? New Directions for Institutional Research, (2015), 165, 3-13.

Jones, M.T., Barlow, A. E. L., \& Villarejo, M. (2010). Importance of undergraduate research for minority persistence and achievement in biology. Journal of Higher Education, 81(1), 82116.

Kendricks, K., Arment, A. (2011). Adopting a K-12 family model alongside undergraduate research to enhance STEM persistence and achievement for underrepresented minority students. Journal of College Science Teaching, 41(2), 64-69.

Kendricks, K., Nedunuri, K. V., Arment, A. (2013). Minority student perceptions of the impact of 
mentoring to enhance academic performance in STEM disciplines. Journal of STEM Education: Innovations and Research, 14(2), 38-46.

Koenig, R. (2009). Minority retention rates in science are sore spots for most universities. Science, 324(5933), 1386-87.

Ladson-Billings, G. (1994). The dreamkeepers: Successful teachers of African American students. San Francisco: Jossey-Bass.

Larson, L., \& Novak, K. (2002). States K-16 education systems. Information Brief: Minnesota House of Representatives Research Department. St. Paul, MN.

Lee, J., \& Darity, W. (2012). An analysis of the institutional factors that influence retention and 6 -year graduation rates at historically black colleges and universities. Retrieved from http://hdl.handle.net/10161/5244

Madden, R. (2005). Doing business with business schools. In R. Paton, G. Peters, J. Storey \& S. Taylor. (Eds.). The handbook of corporate university development: Managing strategic learning initiatives in the public and private domains (pp. 97-107). London: Gower.

Nagda, B., Gregerman, S., Jonides, J., von Hippel, W., \& Lerner, J. (1998). Undergraduate student-faculty research partnerships affect student retention. The Review of Higher Education, 22(1), 55-72.

National Science Board (NSB). (2015). Revisiting the STEM workforce: A companion to the science and engineering indicators report. Arlington, VA: National Science Foundation.

National Science Foundation (NSF). (2012). Science and engineering indicators, higher education in science and engineering highlights. Arlington, VA: National Science Foundation.

National Science Foundation (NSF). (2018). Science and engineering indicators. Arlington, VA: National Science Foundation.

Nestor-Baker, N., \& Kerka, S. (2009). Recruitment and retention of underrepresented students in STEM fields. Columbus, $\mathrm{OH}$ : The Ohio State University.

Noddings, N. (1992). The challenge to care in schools. New York: Teachers College Press.

North, C. (2011). Designing STEM pathways through early college: Ohio's Metro Early College High School. Early College Design Services, Jobs for the Future.

Obama, B. (2016). Presidential State of Union Address: Science, technology, engineering, and mathematics for all: Ensuring high-quality STEM education for all students. Executive Office of the President of the United States, Washington, DC: White House.

Office of Assessment \& Institutional Research. (2009). Central State University factbook. Wilberforce, OH: Central State University.

Office of Assessment \& Institutional Research. (2010). Central State University factbook. Wilberforce, OH: Central State University.

Office of Assessment \& Institutional Research. (2011). Central State University factbook. Wilberforce, $\mathrm{OH}$ : Central State University.

Office of Assessment \& Institutional Research. (2012). Central State University factbook. Wilberforce, $\mathrm{OH}$ : Central State University.

Office of Assessment \& Institutional Research. (2013). Central State University Factbook. Wilberforce, $\mathrm{OH}$ : Central State University.

Office of Assessment \& Institutional Research. (2014). Central State University Factbook. Wilberforce, $\mathrm{OH}$ : Central State University.

Ohio Board of Regents. (2014). Pre-K to jobs: Higher education's role in developing students for careers. Columbus, $\mathrm{OH}$ : University System of Ohio.

Ohio Board of Regents. (2011). Underrepresented Ohioans need more education to meet the state's workforce needs. Columbus, OH: University System of Ohio. Retrieved from 
https://cdn.owens.edu/ie/ConditionReport-4.pdf

Ohio Department of Education. (2014). Ohio remediation report. Columbus, Ohio: University System of Ohio.

Phillips, T. R. (1991). ABET/EBBON minority engineering student achievement profile. New York: Accreditation Board for Engineering and Technology, Inc.

Porter, A., Polikoff, M., Smithson, J. (2009). Is there a de facto national intended curriculum? Evidence from state content standards. Educational Evaluation and Policy Analysis, 31, 238628.

President's Council of Advisors on Science and Technology (PCAST). (2012). Engage to excel: Producing one million additional college graduates with degrees in science, technology, engineering, and mathematics. Washington, DC: Executive Office of the President of the United States.

Roach, R. (2015). STEM success: African-American STEM graduates have benefited from a range of best practices that experts have cited as key factors in STEM student success at the undergraduate level. Diverse Issues in Higher Education, 32(15), 32.

Sasso, A. (2008). African Americans studying STEM: Parsing the numbers. Science. Retrieved from http://www.sciencemag.org/careers/2008/05/african-americans-studying-stemparsingnumbers

Seymour, E., Hunter, A. B., Laursen, S. L., \& Deantoni, T. (2004). Establishing results of research experiences for undergraduates in the sciences: First findings from a three-year study. Science Education, 88(4), 493-534. https://doi.org/10.1002/sce.10131

Slaughter-Defoe. D. T., Garret, A. M., \& Harrison-Hale, A. O. (2006). Affirming future generations of ethnic minority scientists. Monographs of the Society for Research in Child Development, 71, 188-192. https://doi.org/10.1111/j.1540-5834.2006.00369

Somers, C.L., Owens, D., \& Piliawsky, M. (2008). Individual and social factors related to urban African-American adolescents' school performance. The High School Journal, 91(3), 1-11. https://doi.org/10.1353/hsj.2008.0004

Taraban, R., \& Blanton, R. L. (Eds). (2008). To think and act like a scientist: Undergraduate research experiences and their effects. New York, NY: Teachers College Press.

Taylor, R. (2013). National Science Foundation Benjamin Banneker Scholars Program at Central State University evaluation report. Wilberforce, OH: Central State University.

U.S. Bureau of Labor Statistics. (2017). Employment projections 2016-2026. Retrieved from https://www.bls.gov/news.release/pdf/ecopro.pdf

U.S. Census Bureau Report. (2014). National projections. Retrieved from https://census.gov/content/dam/Census/library/publications/2015/demo/p25-1143.pdf

U.S. Commission on Civil Rights. (2010). The educational effectiveness of historically black colleges and universities: A briefing before the United States Commission on Civil Rights. Retrieved from https://files.eric.ed.gov/fulltext/ED513988.pdf

White House Press Release. (2009). Educate to innovate campaign for STEM education. Washington, DC: White House Office of the Secretary.

Wenglinsky, H. (1997). Students at historically black colleges and universities: Their aspirations and accomplishments. Policy Information Report. Princeton, NJ: Educational Testing Service. https://files.eric.ed.gov/fulltext/ED415239.pdf 